\title{
A comparative study of thyroid status of patients on phenytoin, carbamazepine and valproate monotherapy
}

\author{
Dinesh K. Dhodi, Sagar B. Bhagat*, Ketaki C. Patil
}

\begin{abstract}
Department of Pharmacology, Grant Govt. Medical College \& Sir JJ Group of Hospitals, Mumbai, Maharashtra India

Received: 17 December 2015 Accepted: 07 January 2016

\section{*Correspondence to: \\ Dr. Sagar B. Bhagat, \\ Email: sagarbhagat04@ gmail.com}

Copyright: (C) the author(s), publisher and licensee Medip Academy. This is an openaccess article distributed under the terms of the Creative Commons Attribution NonCommercial License, which permits unrestricted noncommercial use, distribution, and reproduction in any medium, provided the original work is properly cited.
\end{abstract}

\begin{abstract}
Background: Anti-epileptic drugs are well tolerated, many effects on endocrine function have been reported, especially, the effect of long-term administration of anticonvulsant drugs on blood thyroid hormone levels.

Methods: An analytical, cross sectional, non-randomized study conducted in Neurology Department over a period of twelve months from November 2012 to October 2013 where in 90 patients was enrolled in the study.

Results: Of the 90 patients 56 were male and 34 were females. Baseline evaluation of the thyroid status of all patients were noted and showed all the 90 patients were clinically and Para clinically euthyroid. Patients on Phenytoin showed serum TSH value (Mean \pm SD) to be statistically higher than the baseline and the normal reference value, whereas no significant difference was noted in the serum free T3 and T4 values. When patients on carbamazepine were evaluated, statistically significant difference was noted in the serum T3 and T4 level and was found to be lower than the reference value. No significant difference was seen in the serum TSH level. Patients receiving valproate showed no significant difference in the serum T3, T4 and TSH before and 6 month after prescription. All the patients were clinically euthyroid and showed no sign and symptoms of hypothyroidism.

Conclusions: Valproate monotherapy does not alter serum levels of thyroid hormones. On the contrary, alterations of thyroid hormone function were seen in patients treated with carbamazepine and phenytoin. However, all the patients were euthyroid and were not associated with clinical or even subclinical hypothyroidism.
\end{abstract}

Keywords: Epilepsy, Thyroid function, Phenytoin, Carbamazepine, Valproate

\section{INTRODUCTION}

Epilepsy is one of the most common neurological disorders having an important medical, social and psychological consequence. Using the definition of epilepsy as two or more unprovoked seizures, the incidence of epilepsy is around 0.3 to $0.5 \%$ in different populations throughout the world, its prevalence has been estimated at 5 to 10 persons per $1000 .{ }^{1}$ Older antiepileptic (AEDs) drugs such as phenytoin, valproic acid, carbamazepine, phenobarbital and ethosuximide are generally used as the first-line therapy for most seizure disorders. ${ }^{2}$ Although these AEDs are well tolerated, many effects on endocrine function have been reported in literature. $^{3}$ Especially, the effect of long-term administration of anticonvulsant drugs on blood thyroid hormone levels. ${ }^{4}$ But studies have also revealed that these patients appear clinically euthyroid with normal reference levels of thyroid stimulating hormone (TSH). ${ }^{5}$

The prime study around the effects of AEDs on thyroid gland was made in 1961 by Oppenheimer et al who met a downfall in iodine bound to serum proteins and a disorder in $\mathrm{T} 4$ secretion from thyroxin binding globulin (TBG) in adults taking phenytoin. ${ }^{6}$ Phenytoin, being an enzyme inducer, has been reported to reduce both free and total T3 and T4 level. ${ }^{6,7}$ Though there have been studies saying that the hypothyroid state induced by phenytoin therapy is not associated with clinical features of hypothyroidism there have been recent reports of clinical hypothyroidism associated with phenytoin toxicity. ${ }^{8-10}$ 
The effect of two of the most frequently used AEDs, carbamazepine (CBZ) and valproate (VPA), on serum thyroid hormone concentrations has been controversial. CBZ therapy can decrease the serum thyroid hormone levels, but generally serum TSH concentrations remain normal except in a small percentage of patients who show increased TSH levels. ${ }^{11,12}$ Though there have been studies suggesting that carbamazepine-induced reduction in thyroid hormone levels is not associated with clinical hypothyroidism, there have been studies suggesting the contrary. ${ }^{13,14}$ Reports on the effect of VPA on the thyroid hormones balance are conflicting, and both low and unchanged serum thyroxine (T4) and free thyroxine (T4) levels have been found in patients receiving VPA monotherapy, never associated with overt thyroid dysfunction. ${ }^{11,15}$

A comparative studies correlating abnormalities of thyroid function tests and clinical thyroid status of patients on monotherapy with the frontline antiepileptic drugs, namely phenytoin, valproate and carbamazepine are lacking, especially in the Indian set-up. Hence this study was planned with the objective to study and compare the thyroid status (free T3, T4 and TSH) of the patients on Phenytoin, Carbamazepine and Valproate and to assess the clinical finding in relation to their thyroid hormone profile.

\section{METHODS}

This was an analytical, cross sectional, non-randomized study conducted in Neurology Department of Grant Govt. Medical College \& Sir J.J. Hospital, Byculla, Mumbai over a period of twelve months from November 2012 to October 2013 where in 90 patients were enrolled in the study. Patients were divided in three groups receiving phenytoin, carbamazepine and valproate monotherapy, so thirty patients were included in each group. The study commenced after approval from the Institutional Ethics Committee and confidentiality of patients was maintained throughout the study period. Patients of either sex above 12 years of age attending neurology OPD, newly diagnosed with any type of epilepsy by the neurologist, receiving phenytoin, carbamazepine or valproate monotherapy for at least 6 months, who were clinically and Para clinically euthyroid and willing to participate in the study by giving written consent were included in the study. The exclusion criteria were as follow: Patients below 12 years of age, pregnant and lactating females, those suffering from uncontrolled seizure or receiving polytherapy or any other antiepileptic drug other than those mentioned above. Patients with past history of Radioactive Iodine therapy or thyroid surgery or those on supplemental thyroid treatment for hypothyroidism and patients with abnormal neurologic examination, malformed cerebral computed tomography (CT) and/or magnetic resonance imaging (MRI), liver or kidney disease, thyroid disease or endocrinopathies and /or those with chronic diseases known to disturb thyroid function were excluded. All the patients were diagnosed and were prescribed the appropriate drug and dose by the practicing neurologist. Serum thyroxine (T4), triiodothyronine (T3) and thyroid-stimulating hormone concentrations were measured in by collecting $0.5 \mathrm{ml}$ of blood in plain bulb under strict aseptic precautions. The collected blood sample was sent for serum $\mathrm{T}_{3}, \mathrm{~T}_{4}, \mathrm{TSH}$ assays. For statistical analysis following values were used and were considered normal: TSH: $0.3-5 \mathrm{U} / \mathrm{ml}, \mathrm{T} 3: 2.3-$ 4.2pg/ml, T4:0.8-2.8ng/dl. ${ }^{16}$ The results of computations were inspected by an endocrinologist to evaluate thyroid function status. All numerical data was analysed using appropriate statistical tests and was expressed as Mean \pm SD. Wilcoxon Signed Ranks Test and Kruskal Wallis test was applied and a $\mathrm{p}$ value of $<0.05$ was considered to be significant for all the tests applied.

\section{RESULTS}

Table 1: Thyroid hormone level before AED prescription.

\begin{tabular}{|llll|}
\hline & Phenytoin & Carbamazepine & Valproate \\
\hline TSH & $1.93 \pm 0.19$ & $1.66 \pm 0.27$ & $1.32 \pm 0.16$ \\
\hline T3 & $3.25 \pm 0.31$ & $3.20 \pm 0.22$ & $3.47 \pm 0.29$ \\
\hline T4 & $1.80 \pm 0.10$ & $1.89 \pm 0.13$ & $2.25 \pm 0.11$ \\
\hline
\end{tabular}

TSH (U/ml), T3 (pg/ml), T4 (ng/ml)

Table 2: Thyroid Hormone level after AED prescription.

\begin{tabular}{|llll|}
\hline & Phenytoin & Carbamazepine & Valproate \\
\hline TSH & $3.55 \pm 1.40$ & $1.70 \pm 0.68$ & $1.22 \pm 0.61$ \\
\hline T3 & $3.12 \pm 0.40$ & $1.90 \pm 0.69$ & $3.54 \pm 0.44$ \\
\hline T4 & $1.66 \pm 0.22$ & $0.72 \pm 0.26$ & $2.22 \pm 0.58$ \\
\hline
\end{tabular}

TSH (U/ml), T3 (pg/ml), T4 (ng/ml)

A total of 90 newly diagnosed epileptic patient receiving phenytoin, carbamazepine and valproate monotherapy for atleast six month and stabilised on it and who were clinically and paraclinically euthyroid patients were enrolled in the study, these patients were divided in three groups, depending on the treatment received. Of the 90 patients $56(62 \%)$ were male and $34(38 \%)$ were females. Age distribution of patients showed majority of 28 patients in adolescent age group. (Figure 1) Baseline evaluation of the thyroid status of all patients were noted and showed all the 90 patients were clinically and paraclinically euthyroid (Table 1). Patients on Phenytoin showed serum TSH value (Mean \pm SD) to be statistically higher than the baseline and the normal refrence value, a significant difference $(P=0.002)$ was noted in the serum TSH level, and was considered significant, whereas no significant difference was noted in the serum free T3 and T4 values (Table 2). When patients on carbamazepine were evaluated, statistically significant difference was noted in the serum T3 $(P=0.001)$ and T4 $(P=0.001)$ level and was found to be lower than the reference value. No significant difference was seen in the serum TSH level (Table 2). Patients receiving valproate showed no significant difference in the serum T3, T4 and TSH 
before and 6 month after prescription (Table 2). All the patients were clinically euthyroid and showed no sign and symptoms of hypothyroidism.

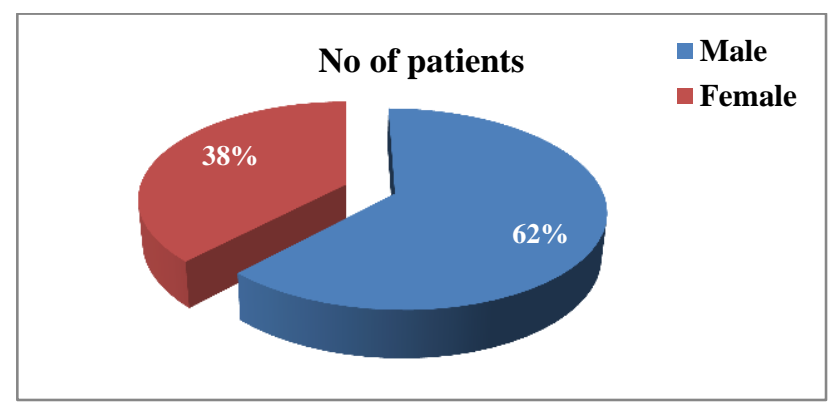

Figure 1: Gender wise distribution of patients.

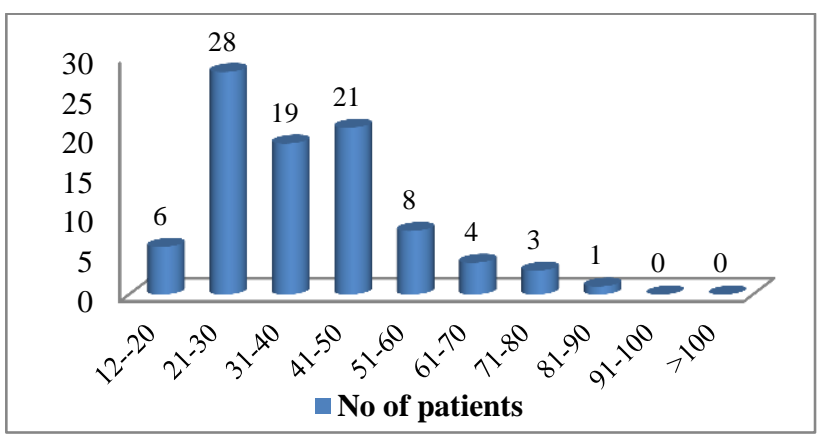

Figure 2: Age distribution of patients.

\section{DISCUSSION}

In this study we evaluated the thyroid status (T3, T4 and $\mathrm{TSH}$ ) of patients on phenytoin, carbamazepine and valproate. The effects of long term administration AEDs on thyroid functions are well known for a long time but the general finding has not been recognized yet. Our study demonstrate that phenytoin treated patients shows increase serum concentration of $\mathrm{TSH}$ whereas $\mathrm{T} 3, \mathrm{~T} 4$ in normal range this was in contrast to the study conducted by Yeo and Bates in 1978 which showed decreased T3, T4 with phenytoin and other studies which showed TSH to be within normal reference range. ${ }^{17-19}$ This may be due to its enzyme induction property, which accelerate the hormone clearance. In our study carbamazepine treated patients showed decrease serum concentration of T3, T4 whereas TSH remains within in normal range. This finding of low serum $\mathrm{T} 4$ concentrations in epileptic patients receiving $\mathrm{CBZ}$ is in coherent with earlier reports. $^{20-27}$ Thus the large majority of these studies and also our data demonstrate that serum $\mathrm{T} 4$ decreased whereas TSH levels remained unchanged. But these patients appeared clinically euthyroid; therefore, the clinical significance of this decrease seems to be minimal; it is possible that $\mathrm{CBZ}$ influences the active transmembrane transport of $\mathrm{T} 4$ in the various tissues (including hypothalamus/pituitary). This hypothesis can explain the euthyroid status of our patients. CBZ-related changes of serum $\mathrm{T} 4$ concentrations have been attributed to induction of the hepatic P-450 enzyme system: inducing this hepatic system, $\mathrm{CBZ}$ is able to increase thyroid hormone metabolism. ${ }^{28,29}$ Valproate on the other side showed no significant change in the serum T3, T4 and TSH concentration, this results were in consistent with the other studies reported earlier in contrast other studies found normal thyroid hormone levels while TSH levels were increased. ${ }^{30-34}$ This may be due to $\mathrm{CBZ}$ and Phenytoin induces hepatic microsomal enzymes markedly in dose-dependent fashion whereas VAL has no significant effect. ${ }^{35}$

\section{CONCLUSION}

Our data suggest that the VPA monotherapy does not alter serum levels of thyroid hormones. On the contrary, alterations of thyroid hormone function were seen in patients treated with $\mathrm{CBZ}$ and phenytoin. However, all the patients were euthyroid and were not associated with clinical or even subclinical hypothyroidism. Therefore from the above study we can conclude that impairment of thyroid function can occur during AED medication therefore a long term follow-up is necessary in case of long term use of this drug.

Funding: No funding sources

Conflict of interest: None declared

Ethical approval: The study was approved by the Institutional Ethics Committee

\section{REFERENCES}

1. Lowenstein DH. Seizures and epilepsy. In: Longo DL, Kasper DL, Hauser SL, Jameson JL, Loscalzo J, Fauci AS, editors. Harrison's principles of internal medicine. 18thed. New York: McGraw Hill. 2011:3251-69.

2. Castro-Gago M, María Inés Novo-Rodríguez. Evolution of Subclinical Hypothyroidism in children treated with antiepilepticdrugs. Pediatric Nourology. 2007;37(6):426.

3. Alberto V, Melissa L, Alessandra S, Emilio F, Francesco C. Thyroid hormones in children with epilepsy during long-term administration of carbamazepine and valproate. European Journal of Endocrinology.(2009;160:81-86.

4. Ramsay I. Drug and non-thyroid induced changes in thyroid function tests. Postgrad Med J. 1985;61:3757.

5. Connacher AA, Borsey DQ, Browning MCK, Davidson DLW, Jung RT. The effective evaluation of thyroid status in patients on phenytoin, carbamazepine or sodium valproate attending an epilepsy clinic. Postgraduate Medical Journal. 1987;63:841-5.

6. Oppenheimer JH, Fisher LV, Nelson KM, Jailer JW. Depresion of the serum protein bound iodine level by diphenylhydantoin. Clin Endocrinol Metab. 1961;2:252-62.

7. Surks MI, DeFesi CR. Normal serum free thyroid hormone concentrations in patients treated with phenytoin or carbamazepine. A paradox resolved. JAMA. 1996;275(19):1495-8. 
8. Tiihonen M, Liewendahl K, Waltimo O, Ojala M, Välimäki M. Thyroid status of patients receiving long-term anticonvulsant therapy assessed by peripheral parameters: a placebo-controlled thyroxine therapy trial. Epilepsia. 1995;36(11):111825.

9. Betteridge T, Fink J. Phenytoin toxicity and thyroid dysfunction. N Z Med J. 2009;122(1303):102-4.

10. Collins RJ. Elevated thyroid-stimulating hormone in a 65-year-old patient with phenytoin toxicity. Consult Pharm. 2008;23(8):610-3.

11. Verrotti A, Basciani F, Morresi S, Morgese G, Chiarelli F. Thyroid hormones in epileptic children receiving carbamazepine and valproic acid. Pediatric Neurology. 2001;25:43-6.

12. Isoja“rvi JIT, Pakarinen AJ \& Myllyla“ VV. Thyroid function with antiepileptic drugs. Epilepsia. 1992;33:142-8.

13. Verrotti A, Laus M, Scardapane A, Franzoni E, Chiarelli F. Thyroid hormones in children with epilepsy during long-term administration of carbamazepine and valproate. Eur $\mathrm{J}$ Endocrinol. 2009;160(1):81-6.

14. Simko J, Horacek J. Carbamazepine and risk of hypothyroidism: a prospective study. Acta Neurol Scand. 2007;116(5):317-21.

15. Zhu S, Liu X, Ruan X, Cai Z. Changes of thyroid hormone levels in epileptic patients. Journal of Tongji Medical University. 1994;14:119-23.

16. http://www.globalrph.com/labs_t.htm.sited on July 10. 2014.

17. Yeo PPB, Bates D, Howe JG. Anticonvulsants and thyroid function. Br Med J. 1978;1:1581-3.

18. Molholm HJ, Skovsted L, Lauridsen UB, Kirkegaard C, Siersback-Nielsen K. The effect of diphenylhydantoin on thyroid function. J Clin Endocrinol Metab. 1974;39:785-9.

19. Rousso I, Pharmakiotis A, Gatzola M, Karatza E, Sklavounou-Tsouroutsoglou S. Effects of phenobarbital, diphenylhydantoin and carbamazepine on thyroid function in epileptic children. Acta Endocrinol. 1984;265:48-49.

20. Isoja“rvi JIT, Pakarinen AJ, Myllyla“ VV. Thyroid function with antiepileptic drugs. Epilepsia. 1992;33:142-8.

21. Cannacher AA, Borsey DQ, Browning MC, Davidson DL, Jung RT. The effective evaluation of thyroid status in patients on phenytoin, carbamazepine or sodium valproate attending an epilepsy clinic. Journal of Postgraduate Medicine. 1987;63:831-51.

22. Haidukewych D, Rodin EA. Chronic antiepileptic drugs therapy:classification by medication regimen and incidence of decreases in serum thyroxine and free thyroxine index. Therapeutic Drug Monitoring. 1987;9:392-8.

23. Ericsson UB, Bjerre I, Forsgren M, Ivarsson SA. Thyroglobulin and thyroid hormones in patients on long-term treatment with phenytoin, carbamazepine, and valproic acid. Epilepsia. 1985;26:594-6.

24. Isoja“rvi JIT, Pakarinen AJ, MyllyIa“ VV. Thyroid function in epileptic patients treated with carbarmazepine. Archives of Neurology. 1989;46:1175-8.

25. Tiihonen M, Liewendahl K, Waltimo O, Ojala M, Valimaki M. Thyroid status of patients receiving long-term anticonvulsant therapy assessed by peripheral parameters: a placebo-controlled thyroxine therapy trial. Epilepsia. 1995;36:810-6.

26. Surks MI, DeFesi CR. Normal serum free thyroid hormone concentrations in patients treated with phenytoin or carbamazepine. Journal of the American Medical Association. 1996;275:1495-8.

27. Bentsen KD, Gram L, Veje A. Serum thyroid hormones and blood folic acid during monotherapy with carbarmazepine or valproate. Acta Neurologica Scandinavica. 1983;67;235-41.

28. Isoja“rvi JIT, Airaksinen KEJ, Mustonen JN, Pakarinen AJ, Rautio A, Pelkonen O, et al. Thyroid and myocardial function after replacing carbamazepine by oxcarbazepine. Epilepsia. 1995;36810-6.

29. Tanaka K, Koda Ma S, Yokoyama S, Komatsu M, Konishi H, Momota K, et al. Thyroid function in children with long term anticonvulsant treatment. Journal of Pediatric Neurosciences. 1987;13:90-4.

30. Fichsel H, Knopfle G. Effects of anticonvulsant drugs on thyroid hormones in epileptic children. Epilepsia. 1978;19:323-36.

31. Liewendahl K, Majuri H, Helenius T. Thyroid function tests in patients on long-term treatment with various anticonvulsant drugs. Clin Endocrinol. 1978;8:185-91.

32. Bentsen KD, Gram L, Veje A. Serum thyroid hormones and blood folic acid during monotherapy with carbamazepine or valproate. Acta Neurol Scand. 1983;67:235-41.

33. Vainionpa“a“ LK, Mikkonen K, Ra“ttya“ J, Knip M, Pakarinen AJ, Myllyla“ VV et al. Thyroid function in girls with epilepsy with carbamazepine, oxcarbazepine, or valproate monotherapy and after withdrawal of medication. Epilepsia. 2004;45:197203.

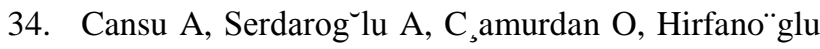
T, Bideci A, Gu"cüyener K. The evaluation of thyroid function, thyroid antibodies, and thyroid volumes in children with epilepsy during short-term administration of oxcarbazepine and valproate. Epilepsia. 2007;47:1855-9.

35. Perucca E, Hedges A, Makki KA, Ruprah M, Wilson JF, Richens AA. Comparative study of the relative enzyme inducing properties of anticonvulsant drugs in epileptic patients. $\mathrm{Br} \mathrm{J}$ Clin Pharmacol. 1984;18:401-10.

Cite this article as: Dhodi DK, Bhagat SB, Patil KC. A comparative study of thyroid status of patients on phenytoin, carbamazepine and valproate monotherapy. Int J Basic Clin Pharmacol 2016;5:3625 . 